Ann. Biol._anim. Bioch. Biophys., I975, 15 (2), 273-280.

\title{
FERTILITY OF ESTRUS SYNCHRONIZED DAIRY HEIFERS TREATED WITH CAP ALONE OR IN COMBINATION WITH ESTRADIOL BENZOATE. HCG OR GnRH
}

\author{
E. GRUNERT \\ Clinic of Bovine Obstetrics and Gynecology \\ at the School of Veterinary Medicine, \\ 3 Hannover, Bischofsholer Dainm 15 (Germany)
}

\section{SUMMARY}

In I970, I97 I and I973 in a single dairy farm a total of 206 German red pied heifers were subjected to synchronization treatment. Treatment schedules consisted of chlormadinone acetate (CAP) given orally daily for I 8 days ro $\mathrm{mg} / \mathrm{day}$ ). Half of the animals were used to measure the effect of additional hormones on conception rate. 3I heifers received $5 \mathrm{mg}$ of estradiol benzoate, 35 animals, I, 000 IU of HCG and 30 heifers $1.5 \mathrm{mg}$ of $\mathrm{GnRH} 24,6$ and 5 hours before the first insemination, respectively. Estrogen treatment had no-effect on the pregnancy rate (30.8 p. Ioo rs. 33.3 p. IOo), treatment with $\mathrm{I}, 000 \mathrm{IU}$ of $\mathrm{HCG}$ decreased the conception rate after insemination in the first post-treatment estrus (53 p. Ioo vs. $3 \mathrm{I} .4$ p. I0o; $\mathrm{P}<0.05)$. An improvement of the pregnancy rate was obtained after injection of $1,5 \mathrm{mg}$ of $\mathrm{GnRH}$ (36.4 p. Ioo vs. 63.3 p. Ioo, $\mathrm{P}<0.05)$. In heifers treated only with $\mathrm{CAP}$ it seems that the occurrence of marked estrous symptoms and the time of ovulation is related with the pregnancy rate. Post-estrual bleeding had no detrimental effect on conception rate. About $80 \mathrm{p}$. Ioo of all experimental heifers, which failed to conceive in the first post-treatment estrus, showed a regular estrous cycle (19-24 days). There was no difference in the average length between the first and second post-treatment estrous cycles.

\section{INTRODUCTION}

In cattle estrus can be successfully synchronized using progestins. The conception rate of the treated animals bred at the first post-treatment estrus was variable, but in general low (HANSEL, I967). Several workers have attempted to improve both the fertility and the degree of synchronization attained following progestin application by injection of additional hormones (estrogen : FULTON et al., I97 I ; Grunert and Schulz, I972; Schmidt et al., I973; Ulberg and LiNdLey, i96o; 
Wiltbank $c t$ al., I965; HCG : BAKER and CogGINs, I968; BOYD and TASKER, I97 I : Grunert and ANDresen, I973; HANSEl et al., I960; Schmidt et al., I973; SPAHR et al., I970; PMSG + HCG : Boyd and TASkER, I97I). These treatments had relatively little success. Only Brown et al. (I973) and WAGNER et al. (I973) obtained an increased conception rate in synchronized cattle after HCG administration.

The objectives of this study were to investigate the improvement of conception rate in CAP-treated heifers by application of estradiol benzoate, HCG or GnRH shortly before the first insemination.

\section{MATERIALS AND METHODS}

This report summarizes experiences obtained during 3 years of studies. In I970, I97 I and I 973 in one dairy farm with optimal farm management a total of 206 German red pied heifers were subjected to synchronization treatment. Half of the animals were usec to measure the effect of additional hormones on conception rate. These hormones were applied shortly before the first insemination after withdrawal of the progestin.

The 20-24-month-old, cycling heifers, kept under relatively constant maintenance and feeding conditions, received in the above mentioned years in November Io $\mathrm{mg} \mathrm{CAP} / \mathrm{head} / \mathrm{day}$ orally for $\mathrm{I} 8$ days. The progestagen was individually administered once daily (morning). In I970 and $197 \mathrm{I}$ the CAP was given in tablets which were powdered and mixed with the concentrate. The intake of the progestin was good, but not always optimal. In I973 CAP was given in a liquicl form. As the solution had an apple-like aroma it proved to be very palatable to the animals, and they ate all the mixed ration eagerly.

In experiment I (1970) 8r heifers were randomly divided into two groups. The following treatment schedules were employed : I) CAP (42 heifers, control); z) CAP', followed by a single injection of $5 \mathrm{mg}$ of estradiol benzoate intramuscularly 24 hours before the first insemination (39 heifers).

In experiment II (I97I) 73 heifers were treated as follows : I) CAP (38 heifers, control): 2) $\mathrm{CAP}$ and I,000 IU of HCG intravenously 6 hours before the first insemination (35 heifers).

In experiment III (I973) the treatment of 52 heifers consisted of : I) CAP ( 22 heifers, control); 2) CAP and $1.5 \mathrm{mg}$ of GnRH intramuscularly 5 hours before the first insemination (3o heifers).

All inseminations were carried out with frozen semen by 2 skilled inseminators at the third and also at the fourth day after withdrawal of CAP. Checks for estrus were made twice daily by observation. In experiment II some animals, which still showed marked signs of estrus were inseminated also at the fifth and sixth day. These animals were daily examined rectally between the third and fifth day after the last $\mathrm{CAP}$ administration. In experiment III the rectal palpations were carried out at the third and fourth day after the last $C A P$-feeding. Pregnancies were confirmed by rectal exploration $6-7$ weeks after the last insemination.

\section{RESULTS}

In experiment I, $39 \mathrm{CAP}$ synchronized heifers with an additional injection of $5 \mathrm{mg}$ of estradiol benzoate showed - if compared with the 42 only CAP-treated ones - a significant improvement of both external signs of heat (behaviour and discharge of mucus) and internal signs (dilation of the cervix, uterine contractions) on the third day after withdrawal of CAP. Despite improvement of the estrous symptoms the pregnancy rate, resulting from the first breeding period, was found similar to that of the 42 control heifers, which received only CAP (30.8 and 33.3 p. Ioo respectively). 


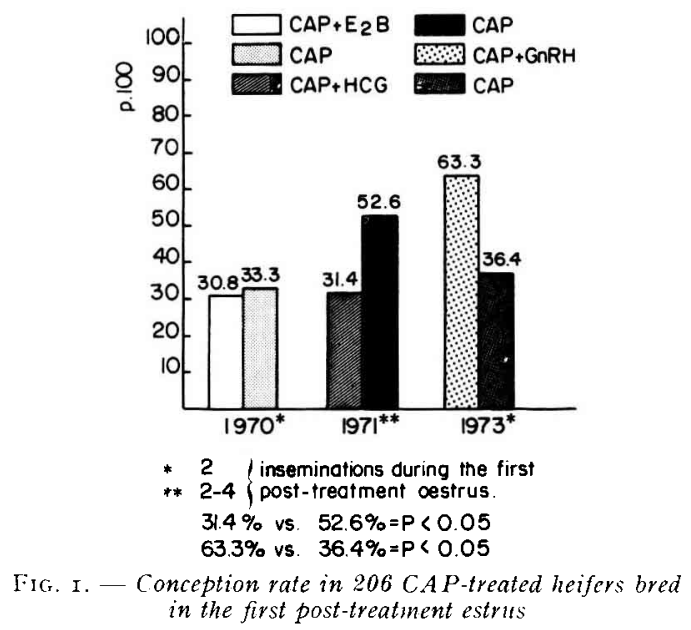

In experiment III I $5.8 \mathrm{p}$. Ioo of the heifers only treated with CAP exhibited marked signs of estrus (behaviour and discharge of clear mucus) on the third day after CAP withdrawal. On the fourth day we observed in $63.2 \mathrm{p}$. Ioo and on the fifth day in 2 r.o p. roo marked estrous symptoms. The corresponding findings in the additional with HCG treated animals were similar $(22.9$ p. Ioo, 60.0 p. Ioo and I7.I p. Ioo, respectively). But these heifers showed a distinct shortening in the duration of both external signs of heat and internal estrous symptoms (dilation of the cervix, uterine contractions, maturation of the follicles). Postestrual bleeding occurred in $60.5 \mathrm{p}$. Ioo of the $38 \mathrm{CAP}$-treated heifers within a period of 3 days, $69.6 \mathrm{p}$. I00 of the postestrual bleeding heifers were found at the sixth day. There was no significant difference concerning the occurrence of postestrual bleeding between the CAPtreated heifers and the synchronized animals which additionally received HCG. 2.6 p. Ioo of the CAP-treated heifers had ovulated until Io $h$ a.m. of the 4 th day and 34.2 p. Ioo until Io $h$ a.m. of the $5^{\text {th }}$ day after withdrawal of the progestin. The percentage of ovulations in the synchronized HCG-treated heifers was until the fourth day (Io h a.m.) 3I.4 p. Ioo and reached until Io h a.m. of the fifth day 74.3 p. Ioo. The conception rate of the CAP-and additional HCG-treated heifers resulting from the first breeding period was found to be $20 \mathrm{p}$. Ioo lower than that of the only CAP-treated ones (3I.4 p. Ioo and 52.6 p. Ioo, respectively; $P<0.05$ ).

In experiment III 68.2 p. Ioo of all synchronized heifers exhibited marked signs of estrus three days and $3 I .8$ p. Ioo four days after the last feeding of CAP. Ovulation occurred until the $4^{\text {th }}$ day ( I I h a.m.) after withdrawal of the progestin in $31.8 \mathrm{p}$. roo of the $22 \mathrm{CAP}$-treated heifers and in $16.7 \mathrm{p}$. Ioo of the $30 \mathrm{CAP}$ and GnRH-treated ones. Postestrual bleeding was observed in 32 of all the 52 synchronized heifers (6r.5 p. IOO) from the fourth until the sixth day after the last feeding of CAP. 53.I p. Ioo of all the 32 postestrual bleeding heifers were found at the 5 th day. There was no apparent difference between the two groups concerning occurrence of estrus and postestrual bleeding. In experiment III the peak of occurrence of heat and post-estrual bleeding occurred one day earlier and the signs of estrus were generally more marked than in experiment II. The pregnancy rate of 
the CAP and GnRH-treated heifers was $26.9 \mathrm{p}$. Ioo higher than that of the CAPtreated animals $(63.3$ and 36.4 p. Ioo, respectively; $P<0.05)$.

In experiments I-III about 80 p. IOO of all animals which failed to conceive in the first post-treatment estrus, showed a regular estrous cycle. 'The percentage of shortened or prolonged estrous cycles does not deviate from non synchronized heifers. Only the heifers which in addition received $5 \mathrm{mg}$ of estradiol benzoate had a high percentage of irregular prolonged estrous cycles. The difference to the other groups is statistically significant $(\mathrm{P}<0.05)$ (fig. 2$)$. There was no difference in the average length between the first and second post-treatment estrous cycles (fig. 3).

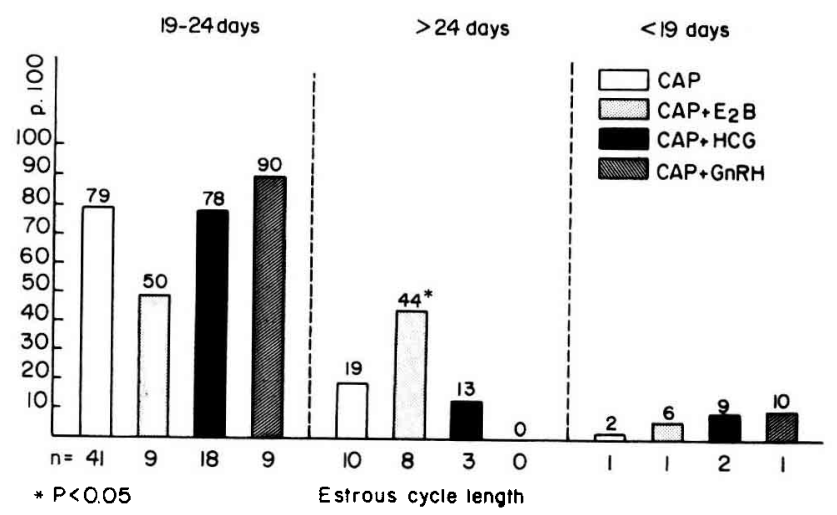

Fic. 2. - Length of estrous cycle in $103 \mathrm{CAP}$-treated dairy heifers, which failed to conceive in the first post-treatment estrus

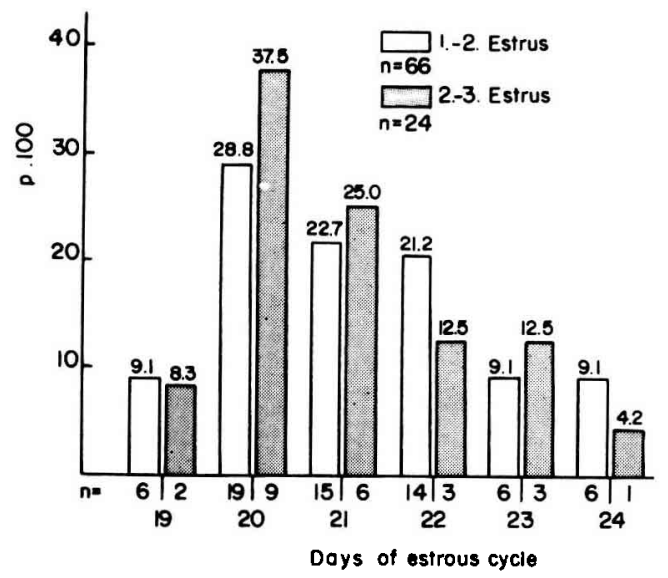

1.IG. 3. - Iength of firs and second synchronized estrous cycle in G6 repcat breeding heifers

\section{DISCUSSION}

The pregnancy rate of the experimental heifers bred at the first estrus following CAP administration ranged between 33.3 and $52.6 \mathrm{p}$. roo. These results are lower than those usually obtained in non-synchronized ones. The precise cause of this subfertility remains unknown. 
The fact that some investigators obtained an excellent fertility in the first synchronized breeding period (VAN BLAKE et al., I963) suggests that in synchronized cattle the fertility is not reduced per se.

In all three experiments the occurrence of the first estrus and also the time of ovulation after withdrawal of CAP were not exactly synchronized. BusCH et al. (I972) reported that in CAP-treated heifers the ovulations scattered over six days. Therefore, no optimal service time could be determined. A better synchronization and a higher conception rate in the first post-treatment estrus were observed after administration of MAP (HANSEL et al., I966). In CAP-treated heifers an improvement of the conception rate could be attained by increasing the number of inseminations in the first estrus after progestin withdrawal. We registered in 1970 and 1973 after a total of 2 inseminations in 24- hour-intervals in the first post-treatment heat a conception rate of 33.3 and $36.4 \mathrm{p}$. Ioo respectively. In I97 I after $2-4$ inseminations under the same conditions the pregnancy rate was $52.6 \mathrm{p}$. Ioo. Busch and SchNel, (I969) obtained with 2-8 inseminations a pregnancy rate of $82 \mathrm{p}$. Ioo in CAP-treated heifers.

Using additional hormones we observed an improvement of the pregnancy rate only after injection of $\mathrm{GnRH} 5$ hours before the first insemination.

Despite improvement of the estrous symptoms in the additionally estradioltreated heifers, the pregnancy rate resulting from the first post-treatment breeding period was found to be similar to that of the control heifers which received only CAP. This finding is in close agreement with that reported by ULBERG and LINDLEY (I960) and Schmid et al. (I973).

The cause of the lowered conception rate in heifers additionally treated with HCG is not known. The ovulation rate in these animals until the 5 th day after withdrawal of CAP was $74.3 \mathrm{p}$. Ioo and in the controls only $34.2 \mathrm{p}$. IOO $(\mathrm{P}<0.00 \mathrm{I})$. A decreased pregnancy rate in CAP- or MAP-synchronized cattle after $\mathrm{HCG}$ application was also obtained by Schmid et al. (I973) and SpAHR et al. (1970).

TABIE I

Relationship bctween the occurrence of marked signs of estrus after withdrawal of CAP and the pregnancy rate

\begin{tabular}{|c|c|c|c|c|c|c|c|}
\hline \multirow{2}{*}{ Treatment } & \multirow{2}{*}{$\begin{array}{l}\text { No of } \\
\text { cattle }\end{array}$} & \multicolumn{2}{|c|}{ Animals in } & \multicolumn{2}{|c|}{ Animals in } & \multicolumn{2}{|c|}{ Animals in } \\
\hline & & $\begin{array}{l}\text { heat or } \\
3 r d \text { day }\end{array}$ & $\begin{array}{c}\text { animals } \\
\text { pregnant }\end{array}$ & $\begin{array}{l}\text { heat on } \\
4 \text { th day }\end{array}$ & $\begin{array}{l}\text { animals } \\
\text { pregnart }\end{array}$ & $\begin{array}{l}\text { heat on } \\
\text { 5th day }\end{array}$ & $\begin{array}{l}\text { animals } \\
\text { pregnant }\end{array}$ \\
\hline $\mathrm{CAP}^{\prime}(1971)(1)$ & 38 & b) & 1) & $\because \prime$ & $17(70.8 \%)$ & 8 & $3(37.5 \%)$ \\
\hline CAP $(1973)\left(^{2}\right)$ & $\underline{2}$ & 15 & $7(16.7 \%)$ & 7 & $1(14.3 \%)$ & & \\
\hline $\mathrm{CAP} \div \mathrm{GnRH}\left({ }^{2}\right)$ & 30 & 23 & $13(56.5 \%)$ & $7^{*}$ & $j(71.4 \%)$ & & \\
\hline
\end{tabular}

(1) 2-4 inseminations during the ist synchronized estrus.

(2) 2 inseminations during the 1 st synchronized estrus.

* 2 heifers without marked signs of estrus. 
The increased conception rate in synchronized cattle after $\mathrm{HCG}$ administration reported by BROWN et al. (I973) and WAGNER et al. (I973) may be attributed to the differences concerning time and route of $\mathrm{HCG}$ application.

It seems that the conception rate of heifers treated only with CAP is related to the appearance of marked estrous symptoms (table I). It seems also that the pregnancy rate of these heifers is related with the time of ovulation (table 2). Concerning the fact that the animal numbers in experiment III is small, the difference is not significant. The difference between the CAP-treated heifers which ovulated after the fourth day and the corresponding additionally with $\mathrm{GnRH}$ treated animals is significant $(\mathrm{P}<0.05)$. This led to the conclusion that $\mathrm{GnRH}$ had an effect on synchronized heifers which did not ovulate until the fourth day after withdrawal of CAP (table 2).

TABIE 2

Relationship between the time of ovulation after withdrawal of C.4P and the pregnancy rate

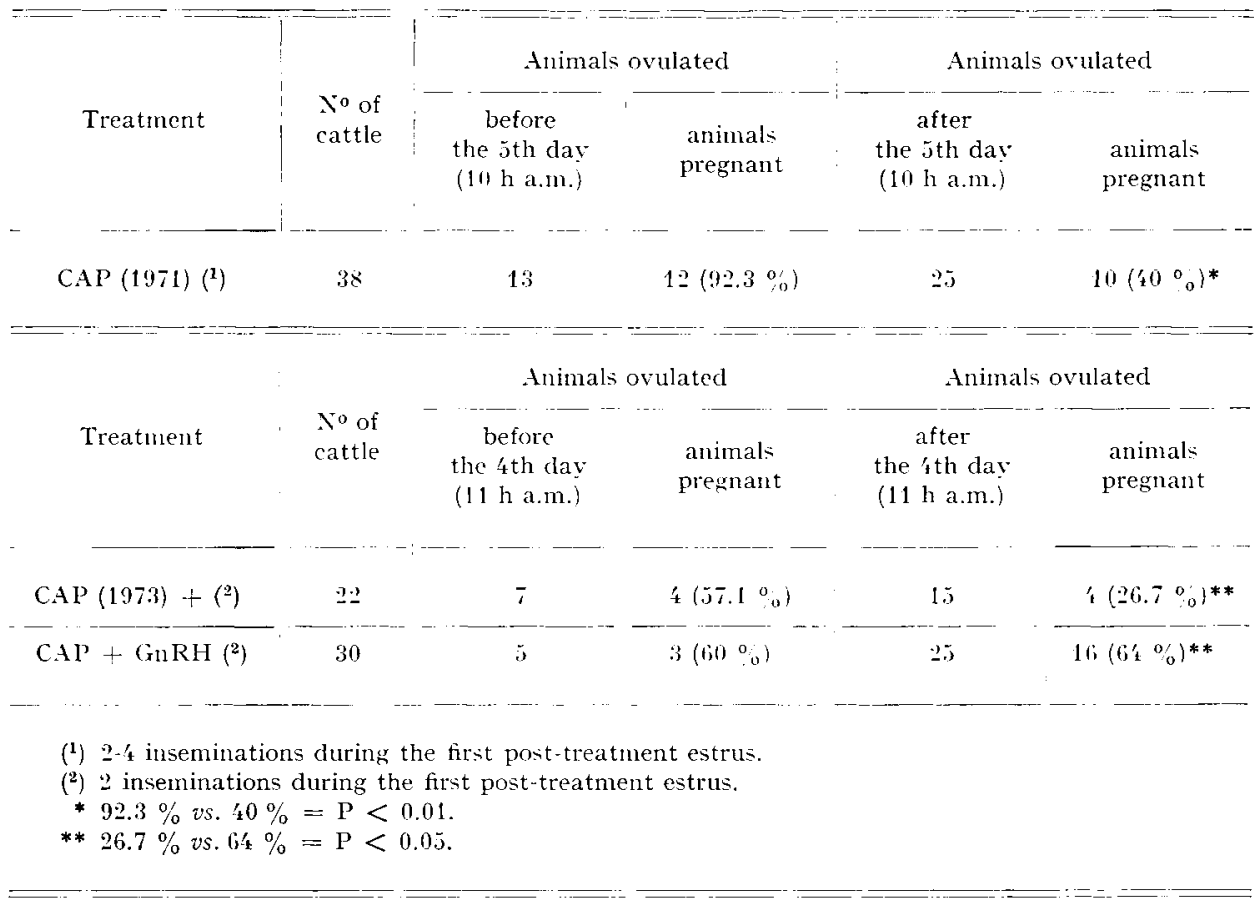

In all three experiments postestrual bleeding did not influence the pregnancy rate. $49 \mathrm{p}$. Ioo of the CAP-treated heifers with metrorrhagia and $5 \mathrm{I} \mathrm{p}$. Ioo of the non bled synchronized heifers conceived.

The three experiments have led to the following conclusions :

I. After individually feeding dairy heifers with ro $\mathrm{mg}$ of CAP per day for I 8 days estrus and the time of ovulation scattered over more than 3 days. Therefore, no optimal service time could be determined. 
2. In heifers only treated with CAP the conception rate ranged from 33.336.4 p. I0o, where these heifers were artificially inseminated without regard to estrus on Days 3 and 4 following the cessation of CAP feeding.

3. Using additional hormones a significant improvement of the pregnancy rate in CAP synchronized dairy heifers was only obtained by injection of $\mathbf{I} .5 \mathrm{mg}$ of $\mathrm{GnRH} 5$ hours before the first insemination.

4. The high percentage of regular estrous cycles in the synchronized repeat breeding heifers suggests that the major causes of the reduced fertility are to be found in events occurring at or about the time of ortulation and fertilization (HANSEI, Ig67).

Colloque : Control of sexual cycles in domestic animals October 27-30, 1974, Nouzilly.

\section{RÉSUMÉ}

FERTILITÉ A L'CESTRUS SYXCHRONISÉ CHEZ DES GÉNISSES TRAITÉES AU CAP SEUL OU EN COMBINAISON AVEC DU BENZOATE D'GSTRADIOL DE L'HCG OU DU GnRH

En 1970, 1971 et 1973, 206 génisses Pic-rouges appartenant au même élevage laitier ont été soumises à un traitement de synchronisation des cycles œestriens à l'aide d'une administration orale et journalière de chlormadinone acétate (CAP) pendant r 8 jours (Io mg/jour). La moitié des animaux a été utilisée pour analyser l'effet d'une addition d'autres hormones sur la fertilité.

Trente et une génisses ont reçu $5 \mathrm{mg}$ de benzoate d'cestradiol, 35 I ooo UI de HCG et 30 I, 5 mende GnRH respectivement 24,6 et 5 heures avant la première insémination. Le traitement d'œestrogènes n'a pas eu d'effet sur le pourcentage de gestations $(30,8$ p. Io0, 33.3 p. 100). Le traitement avec I ooo UI de HCG a diminué le pourcentage de fertilité après insémination lors de la première chaleur après traitement. Après injection de $I, 5 \mathrm{mg}$ de $\mathrm{GnRH}$ on obtient une augmentation du pourcentage de fécondité $(36,4$ p. $100,63,3$ p. I00, $P<0,05)$. Chez les génisses traitées simplement avec du CAP il semble que les symptômes de chaleurs extériorisés et le moment de l'ovulation soient en relation directe avec le pourcentage de fertilité. Un saignement post cestral n'a pas d'effet précis sur la fécondité. 80 p. roo des génisses soumises à l'essai, qui n'ont pas été fécondées, montraient un cycle cestral régulier (19-24-jours). Il n'y a pas de différence en ce qui concerne la durée movenne du premier et du second cycle après le traitement.

\section{REFERENCES}

BAKER R. D., Cogatis E. G., I968. Synchronization of estrus and artificial insemination in beef cattle. Can. J. Anim. Sci, 48, 303-306.

Boyd L. J., TASker J. B., 1971. Fertility of estrus synchronized dairy cattle treated with gonadotropins and inseminated at a predetermined time. I et. Rec., 89,632-635.

Brown H., Wagner J. F., Rathmacher R. P., Mcaskili, J. W., Elligston N. G., Bing R. l', 1973. Effect of human chorionic gonadotropin on pregnancy rate of heifers, when used under field conditions. J. Am. Vet. Med. Ass., 162, 456-457.

Buscil W., Docke F., Flick D., Riebe W., i972. Cntersuchungen zur Beeinflussung des Ovilationstermines und der lertilität nach Brunstsynchronisation bei Färsen. Monatsh. Ieterinärmed., 27, 529-534.

Busch W., Schiell U., I969. Versuche zur Jrunstsynchronisation bei Rindern nit Chlormadinon. Fortpfl. Haust., 5, 301-315.

Fulton R. K., Ball L. E., Wiltbank J. I., I97I. Estrous control with chlormadinone acetate and estrogen. J. Anim. Sci., 33, 254.

Grunert E., Axdresen P., I973. Brunst und Konzeption von Rindern nach Zyklussynchronisation und HCG-Applikation. Dtsch. Tierärztl. Wochenschr., 80, I 52-154. 
Grtnert E., Schulz L.-C., 1972. Brunst, Konzeption und Endometriumbefund von Rindern nach Zyklussynchronisation und Ostrogenapplikation. Zuchthygiene, 7, 97-103.

Hansel W., Donaldson L. E., Wagner W. C., Brunner M. A., I966. A comparison of oestrolis cycle synchronization methods in beef cattle under feedlot conditions. J. Anim. Sci., 25, 497-503.

Hansel W., r967. Control of the ovarian cycle in cattle. A review. Austr. Iet., 43, 44I-449.

Hansel W., Mclintee K., Wagner W. C., I960. Conception rates of repeat-breeder cows bred after progesterone and chorionic gonadotrophin treatments during estrus. Corn. Vet., 50, 497-502.

Hansel W., Malvex P. V., Black D. L., I96r. Estrous cycle regulation in the bovine. J. Anim. Sci., 20,62r-625.

Schmide J., Jöchle W., Smidt D., 1973. Oestrous cycle synchronization and oestrus induction in indigenous and Iuropean cattle in Tanzania. J. Agric. Sci. comb., 81, 38I-389.

Sitton G. D., Smith L. E., MeGraine S. E., Smart L. J., Vincent C. K., ig7i. Synchronization of oestrus with Norethandrolone implants. J. Anim. Sci., 32, 392.

Spahr S. L., Hay's R. L., Graves C. N., i97o. Estrous control for dairy cattle. J. Anim. Sci. 31, $23 \mathrm{I}$.

UlberG L. C., LiNDley C. E., I960. Use of progesterone and estrogen in the control of reproductive activities in beef cattle. J. Anim. Sci. 19, II32-II42.

Van Blake H., Brunner M. A., Hansel. W., I963. Use of G-chloro-6-dehydro-I7-acet-oxyprogesterone (CAP) in estrous cycle synchronization of dairy cattle. J. Dairy Sci., 46, 459-462.

Wagner J. F., Veenhuizen E. L., Tonkinson L. V., Rathmacher R. P., i973. IEffect of placental gonadotropin on pregnancy rate in the bovine. J. Anim. Sci., 36, I I29-1 136.

Wiltbank J. N., Zimmerman D. R., Ingalis J. J., Rowden W. W., r965. Use of progestational compounds alone or in combination with estrogen for synchronization of estrous. J. Anim. Sci., 24, 990-994. 